mgochna@wp.pl

ELŻBIETA KOWALCZYK-HEYMAN

ekowalczyk@uw.edu.pl

Instytut Historii PAN

\title{
NAZWY PRZENIESIONE NA MAZOWSZU WSCHODNIM I PÓŁNOCNO-WSCHODNIM (KONIEC XIV-XV WIEK)
}

Słow a tematyczne: Mazowsze, średniowiecze, przenoszenie nazw, toponomastyka

Ostatnia ćwierć XIV i XV wiek to okres podjętego przez księcia Janusza I i kontynuowanego przez jego następców ponownego zasiedlania Mazowsza wschodniego i północno-wschodniego po zniszczeniach spowodowanych najazdami jaćwiesko-litewskimi. Nowymi osadnikami była szlachta pochodząca zwykle z innych ziem księstwa mazowieckiego. W wyniku tej działalności powstały setki nowych wsi. Ich nazwy mają zróżnicowaną genezę. Są wśród nich onimy utworzone od nazw osobowych noszonych przez nowych osadników, nazwy przeniesione z nazw ich wsi rodzinnych oraz nazwy od nazw elementów pokrycia terenu, czyli wodnych i terenowych. Niestety stan podstawy źródłowej nie w każdym przypadku pozwala jednoznacznie określić genezę poszczególnych nazw, a tym samym ustalić ich przynależność do grup klasyfikacji semantyczno-słowotwórczej (znaczeniowo-formalnej) W. Taszyckiego (1958: 228-268), zwłaszcza, że zabrakło w niej nazw wtórnych. Na istnienie nazw nieobjętych tą klasyfikacją zwrócił już uwagę S. Rospond (1957: 21-22), uznając, że wydzielone w niej nazwy zdrobniałe są w rzeczywistości nazwami wtórnie topograficznymi. W następnych latach doszło do wydzielenia nowych grup klasyfikacyjnych, wśród których znalazły się nazwy wtórne, ale ich zdefiniowanie i podział wewnętrzny dokonywały się stopniowo. Zawdzięczamy to kolejnym toponomastom, do których należeli przede wszystkim J. Bubak (1965: 50-73; 1966: 43-62), J. Treder (1979: 10-43) i H. Borek (1988: 43-51).

J. Bubak nazwy przeniesione podzielił na dwie grupy: nazwy różnego pochodzenia, mające w każdym przypadku indywidualną motywację, i nazwy pochodzenia chrześcijańskiego o motywacji kultowej. Jego zdaniem, obie grupy należą prawie w całości do nazw kulturowych wedle klasyfikacji W. Taszyckiego, wyjątkowo do nazw topograficznych.

Rozwijając problematykę badawczą omawianych nazw, J. Treder uznał, że nie ma znaczenia ich pierwotna etymologia i wewnętrzna struktura, a wagę podstawową ma sposób i powód, dla którego zostały one przeniesione z obiektu na obiekt, bez 
względu na jego położenie w Polsce czy poza jej granicami. Badacz ten wyróżnił dwie podgrupy tego typu onimów: nazwy przeniesione ponowione i nazwy przeniesione importowane. Pierwsza podgrupa obejmowała nazwy urobione „od podstaw dla konkretnego obiektu przez tę samą społeczność (rozumianą historycznie), która z określonych przyczyn przeniosła ją na inny obiekt, leżący w tym samym miejscu co pierwotny, zwykle w bezpośrednim sąsiedztwie" (1979: 22).

Nowe wartości do dyskusji wniósł H. Borek, wprowadzając zamiast terminu nazwy zdrobniałe (z klasyfikacji Taszyckiego) określenie nazwy relacyjne, tzn. takie, które „nie posiadają apelatywnych treści semantycznych” i są pochodzenia odtoponomicznego, czyli ich bazą była istniejąca nazwa geograficzna. Badacz podzielił je na pięć podgrup: nazwy ponowione, przeniesione, dyferencyjne, lokalizujące, pamiątkowe i wariantowe. Był też przeciwny używaniu określeń nazwa relacyjno-topograficzna czy relacyjno-kulturowa (Borek 1988: 47).

Trzeba też odnotować pogląd M. Karasia, który na marginesie rozważań o zróżnicowanej genezie patronimików wydzielił grupę nazw z formantem -ice powstałych od nazw miejscowych. Omawiając natomiast klasyfikację znaczeniowa, stwierdził, że „zbyt wielką autonomię przyznaje się nazwom, czyni je środkiem nadmiernie teoretycznych i niedostatecznie umotywowanych wniosków dotyczących historii nazw, ich powstania, zbyt łatwo uogólnia informacje jednostkowe, a nawet niekiedy pomija dane historyczne względnie do nich nie sięga, gdy tymczasem - jak się okazuje — zawsze konieczna jest znajomość okoliczności powstania nazwy" (1971: 71, 83-84).

Przejdźmy do istniejących opracowań nazw miejscowych na badanym obszarze. W starszych pracach analizujących materiał z tego obszaru Mazowsza (Górnowicz 1967, 1968; Halicka 1976, 1978; Zierhoffer 1957) nazwy miejscowe klasyfikowano wedle podziału W. Taszyckiego, co nie dziwi. Bywa on również stosowany — bez uwzględnienia klasyfikacji nowszych — także w niektórych publikacjach ukazujących się w ostatnich latach (np. Sędziak 2002, 2003, 2004a, b, 2006, 2008, 2009), co powoduje, że niektóre procesy nazewnicze zachodzące na Mazowszu północno-wschodnim nie są właściwie zinterpretowane.

Poniższe rozważania mają na celu przybliżenie zagadnienia nazw przeniesionych na wybranych przykładach z toponimii ziem: łomżyńskiej, wiskiej i liwskiej w kontekście ich przydatności do badań osadniczych. Wydzielenie tej kategorii nazw i ustalenie ich rodowodu może ułatwić: wskazanie obszarów przeludnionych na Starym Mazowszu, zróżnicowanego nasilenia akcji osadniczej w czasie i przestrzeni na Mazowszu wschodnim i północno-wschodnim, mobilności członków poszczególnych rodzin i rodów herbowych, a nawet kryteriów wyboru miejsc nowego osiedlania się.

W poszukiwaniu nazw przeniesionych, wówczas gdy nie dysponowaliśmy bezpośrednimi przekazami źródłowymi, pomocą były analogiczne nazwy wsi, głównie na Starym Mazowszu, których właściciele mieli te same herby, oraz — choć mniej 
pewne - kryterium imienne. Obecnie posłużyliśmy się platformą cyfrową stworzoną w Zakładzie Atlasu Historycznego Polski Instytutu Historii PAN w Warszawie.

Platforma ta nosi nazwę Atlas Fontium (dawniej „Atlas Źródeł i Materiałów do Dziejów Dawnej Polski"; Atlas Fontium). Z jednej strony funkcjonuje ona jako cyfrowe czasopismo naukowe, mające własny numer ISSN, z drugiej zaś przeznaczona jest do gromadzenia, integracji i analizy danych badawczych. Wyposażona została w wyszukiwarki, pozwalające na przeglądanie danych z poszczególnych publikacji na niej zamieszczonych, a także w multiwyszukiwarkę, dzięki której użytkownik może znaleźć interesujące go treści we wszystkich publikacjach umieszczonych w witrynie. Zamierzeniem twórców Atlas Fontium było takie przygotowanie struktury strony internetowej i baz danych, aby można je było integrować z innymi serwisami, np. ze stroną internetową Słownika historyczno-geograficznego ziem polskich w średniowieczu (SHG). Wszelkie zamieszczone w witrynie publikacje podzielone zostały na dwie grupy. Pierwszą z nich (Publikacje) stanowią publikacje sensu stricto, a więc te, które przeszły przez system recenzji i zostały zaakceptowane przez Redakcję. Prace nad nimi zostały zakończone i nie wprowadza się do nich żadnych poprawek (obecnie cztery publikacje: CRP 2014; RPKal; RPPoz; Pacuski 2015). Druga grupa (Prace $w$ toku) zawiera materiały bieżące, które nie przeszły jeszcze etapu recenzenckiego. Są one ciagle aktualizowane i rozbudowywane (obecnie pięć publikacji: Korona; J. Szady 2014; Ptaszyński (red.) 2014; B. Szady 2016; Panecki, Związek 2016).

Spośród wymienionych wyżej opracowań szczególną uwagę w kontekście naszych rozważań zwrócić należy na dwa z nich: bazę danych Ziemie polskie Korony w XVI w. (dalej: Korona) oraz Materiaty do stownika historyczno-geograficznego ziemi liwskiej w średniowieczu i XVI wieku (dalej: Materiaty; Pacuski 2015).

Przestrzenna baza danych Korona powstała podczas prac nad serią Mapy szczegółowe XVI wieku atlasu historycznego Polski. Obejmuje ona opracowane do tej pory dawne województwa: lubelskie, rawskie, płockie, mazowieckie, sandomierskie, sieradzkie, łęczyckie i krakowskie (AHPLub; AHPMaz; AHPSand; AHPSŁ; AHPKrak). Dodatkowo zawiera mapy województw: chełmińskiego, pomorskiego i malborskiego, przygotowane w serii Mapy przegladowe atlasu historycznego Polski (AHPPrusy). W skład wspomnianej bazy wchodzą również mapy województwa kaliskiego, poznańskiego, podlaskiego, brzesko-kujawskiego i ziemi dobrzyńskiej, nad którymi trwają obecnie prace. Mają się one zakończyć w 2020 r., wraz z zakończeniem prac nad całą bazą danych.

Treść prezentowana w Koronie odpowiada treści przedstawionej na Mapach szczegółowych XVI wieku (w tej części, która została przygotowywana w obrębie tej serii; w pozostałych przypadkach informacje są na bieżąco uzupełniane). Można tam odnaleźć zrekonstruowane granice jednostek terytorialnych państwowych (województwa, powiaty) i kościelnych (parafie, dekanaty, archidiakonaty, diecezje), a także ponad 20 tys. punktów osadniczych z określeniem ich przynależności teryto- 
rialnej, charakteru osady (wieś, młyn, osada młyńska, inna), własności (szlachecka, duchowna, królewska, miejska, mieszana). Podane zostały także nazwy osad: szesnastowieczna (główna nazwa osady pojawiająca się w źródłach z drugiej połowy XVI w.), odmianki nazwy (jeśli były wówczas używane na określenie danej osady) oraz nazwa współczesna. Dodatkowo każdej miejscowości nadany został unikalny identyfikator, pozwalający na łączenie ze sobą danych różnego rodzaju (przestrzennych, statystycznych, innych). W bazie umieszczone są także rzeki i jeziora (rekonstrukcja stanu na koniec XVIII w. według założeń serii „Mapy Szczegółowe XVI w.").

Publikację można przeglądać na stronie internetowej przez moduł wyszukujący lub aplikację web-GIS. W przypadku badań nad nazwami ponowionymi szczególnie istotne znaczenie mają wyszukiwarki umieszczone w aplikacji. Pierwsza z nich oferuje proste wyszukiwanie według nazw miejscowości, druga z kolei (SQL) umożliwia szukanie z użyciem wielu kryteriów. I tak, wpisując np. Roguszyn, w wyniku wyszukiwania otrzymamy listę następujących miejscowości: Roguszyno, woj. mazowieckie, pow. zakroczymski, par. Miączyno Małe oraz R.-Wypychy, R. Stare, R.-Decie-Katy, $R$.-Leśniki, $R$. Nowe w tym samym województwie, w pow. liwskim, par. Pniewnik i Czerwonka.

Oprócz wyszukiwania w aplikacji web-GIS lub w wyszukiwarce umieszczonej bezpośrednio na stronie publikacji istnieje również możliwość pobrania warstw GIS i tabel w celu przeprowadzania dalszych analiz na komputerze użytkownika. Jest to podstawa do przestrzennego systematyzowania własnych danych badawczych. Załączone do niniejszego artykułu mapy powstały właśnie na bazie tych danych.

Drugą publikacją prezentowaną w witrynie Atlas Fontium, na którą chcielibyśmy zwrócić uwagę, są przygotowane przez K. Pacuskiego Materiały. Zawierają one informacje źródłowe zgromadzone przez autora w toku wieloletniej pracy, uszeregowane według kryteriów przyjętych przez zespół Słownika historyczno-geograficznego ziem polskich w średniowieczu (Jurek 2010-2016). Z publikacji można korzystać na wiele sposobów: pobrać plik pdf z całym tekstem i mapa, pobrać tabelę w formacie xls lub też przeglądać całość na stronie Atlas Fontium za pomocą aplikacji web-GIS. W tym ostatnim przypadku informacje z Materiałów zostały przyporządkowane poszczególnym punktom osadniczym na mapie. Dzięki temu użytkownik przechodzi od mapy do tekstu a nie — jak ma to miejsce w dwóch innych wspomnianych formach przeglądania — od tekstu do mapy.

Zarówno w bazie Korona, jak i w Materiałach istnieją dwa poziomy wyszukiwania. W kontekście naszych rozważań szczególnie istotna jest funkcja szukania zaawansowanego (przy użyciu kodu SQL). Pozwala ona na wydobycie informacji ze wszystkich danych przyporządkowanych do osad zlokalizowanych, np. osób pojawiających się w zapiskach. Rezultatem tej operacji jest tabela $\mathrm{z}$ wynikami oraz automatyczne zaznaczenie na mapie tych osad, w których szukane treści zostały 


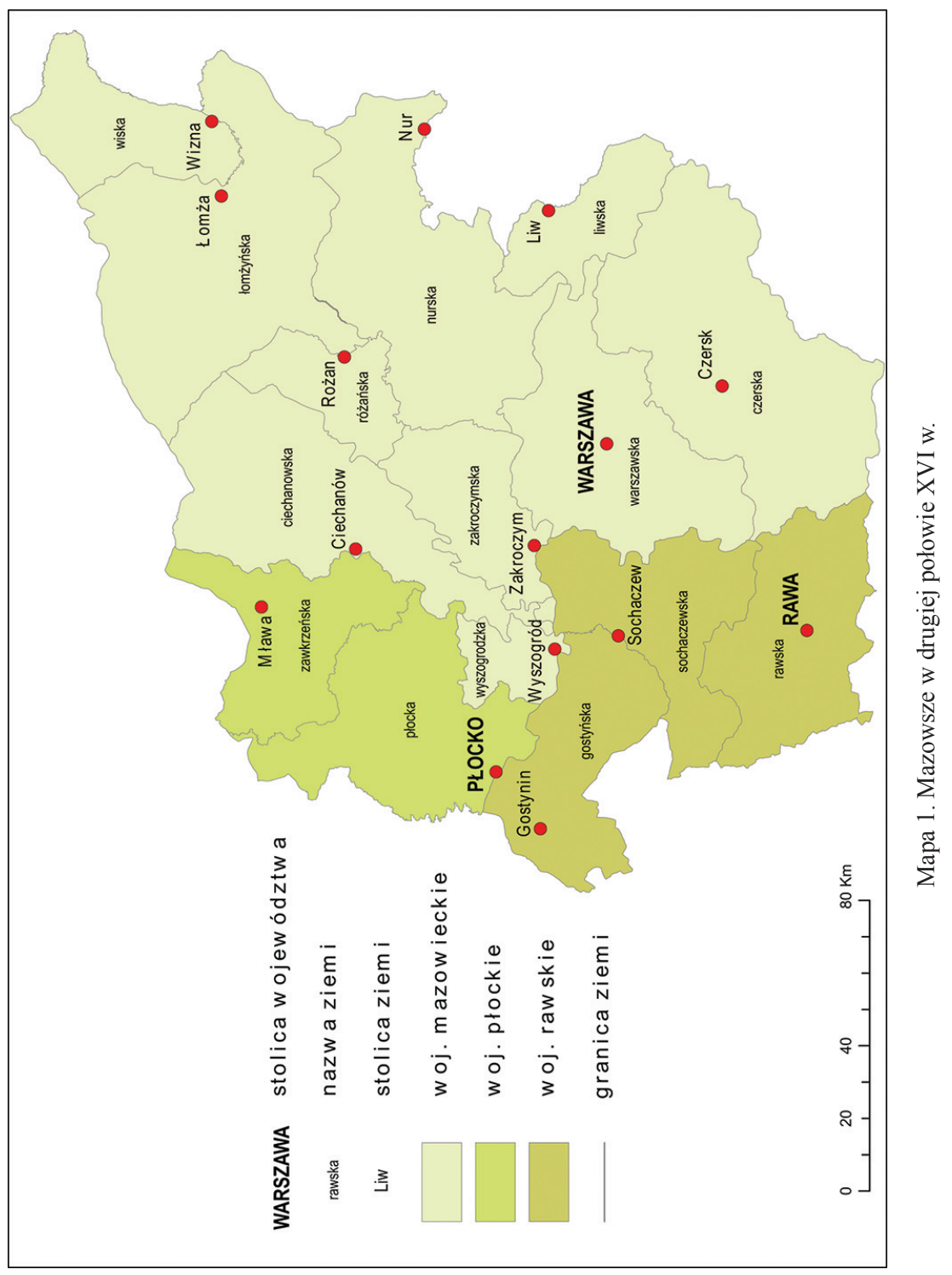


odnalezione. Chcąc z kolei przeszukiwać informacje ze wszystkich haseł, w tym odnoszących się także do osad niezlokalizowanych i obiektów topograficznych, należy pobrać plik pdf lub xls.

Przedstawione publikacje stanowią pomoc na początkowym etapie badań nad nazwami ponowionymi. Jeśli miejscowości istniały w drugiej połowie XVI w., można je szybko odnaleźć w aplikacjach web-GIS za pomocą obu wspomnianych wyszukiwarek. Dotyczy to miejscowości o tożsamych lub podobnych nazwach z tej części Korony, która już została opracowana podczas prac nad Atlasem historycznym Polski, a więc nie tylko z Mazowsza. Osady z województw mazowieckiego, płockiego i rawskiego mają komplet danych nazewniczych kwestionariusza serii atlasowej, a więc nazwę szesnastowieczną, odmianki (jeśli takie odnotowano) i współczesną, co znacznie ułatwia poszukiwanie nazw przeniesionych.

Wśród nazw uwzględnionych w niniejszym artykule znajdą się takie, które zachowały swoją pierwotną budowę, ale i takie, które z czasem uległy przemianom fonetycznym i strukturalnym. Wskażemy trudności w określeniu genezy niektórych z nich. Zwrócimy uwagę na równoległe używanie nazw obocznych, zazwyczaj ponowionych z zastanych nazw elementów pokrycia terenu, i na zastępowanie nazw przeniesionych nowymi nazwami, utworzonymi od odmiennych podstaw. Przywołamy pojawiające się w opracowaniach przykłady błędnych ustaleń co do genezy i podstaw nazw oraz lokalizacji osad, które rzutowały na klasyfikację nazw oraz czas ich pierwszego poświadczenia. Często bowiem zdarza się, że nowej wsi przypisywano zapis odnoszący się w rzeczywistości do wsi rodzinnej odbiorcy nadania.

Na początku podamy przykłady nazw, które w ciągu stuleci nie zmieniły swej budowy, choć niekiedy w wyniku procesów osadniczych stawały się członami utożsamiającymi nazw zestawionych, powstałych najczęściej w wyniku działów rodzinnych.

Nazwą taką jest Chrzanowo, gm. Jedwabne, w ziemi wiskiej (zob. mapę 2). Została ona przeniesiona z nazwy wsi ziemi różańskiej, po nadaniu z $1426 \mathrm{r}$. dla Mścisława z Chrzanowa, gm. Rzewnie (PPr V, nr 480). Nowa wieś ma nazwę poświadczoną od 1436 r. - Chrzanowo (Kapica, nr 65). Nie jest to zatem nazwa dzierżawcza (Halicka 1976: 36), a przeniesiona. Później powstała nazwa zestawiona Chrzanowo Wipichy (1577, ŹDZ XVI 359) oraz kolejne nazwy zestawione z członami wyróżniającymi: Nadolne (Perthées 1783), Szlacheckie i Włościańskie (1921 r., Skorowidz V 36). Nazwę Chrzanowo przejęła także sąsiednia wieś Cyprki i w 1827 r. odnotowano nazwę Chrzanowo Cyrki (!) (Tabella I 72), poprawnie zapisaną w 1839 r. jako Chrzanowo Cyprki (Kwater, kol. V, sek. 2).

Inna nazwa przeniesiona to Chojnowo, gm. Szczuczyn, w ziemi wiskiej, wieś założona przed 1425 r. przez Borzyma i Szczepana z Chojnowa, gm. Czernice Borowe, w ziemi ciechanowskiej (MK 335, 80v). Pierwsze poświadczenie nazwy nowej wsi podchodzi z 1435 r. - Choynowo (MK 3, 131). Nie jest to zatem nazwa 


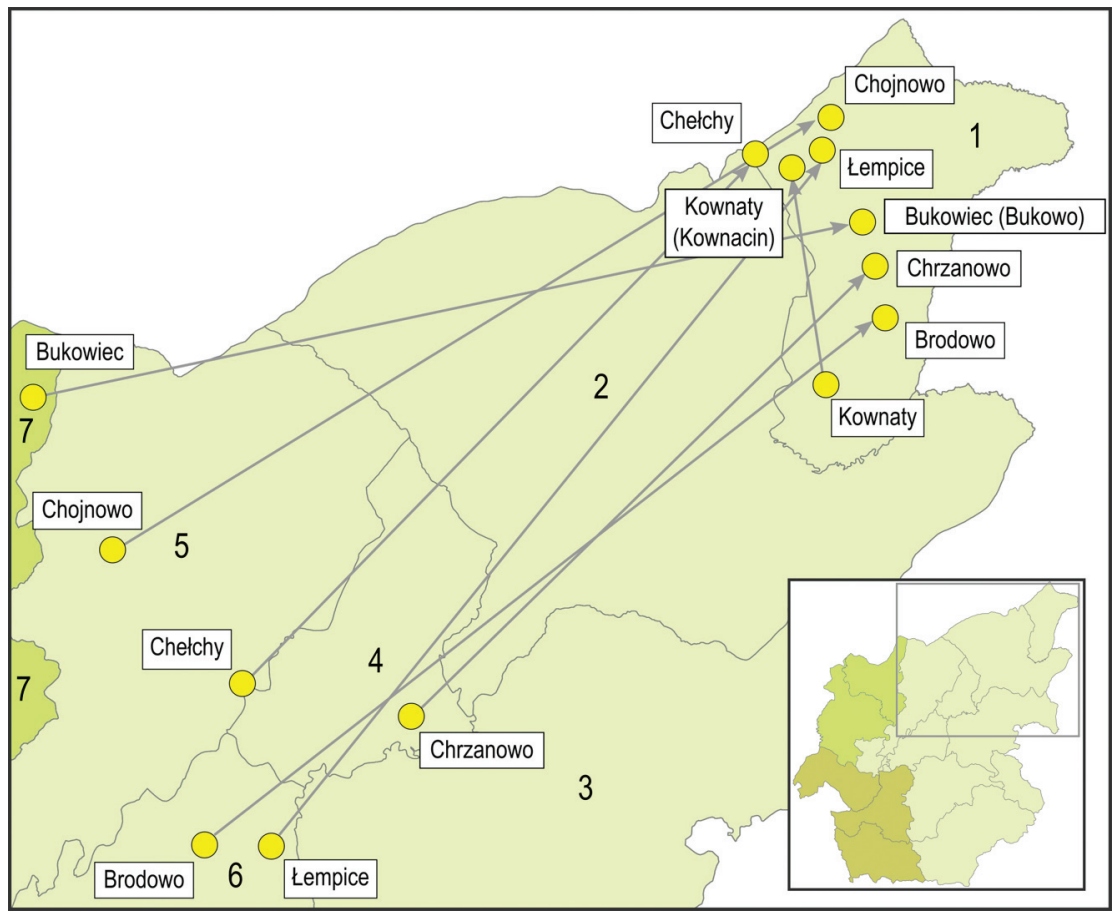

Mapa 2. Wybrane nazwy przeniesione w ziemi wiskiej (woj. mazowieckie: 1 - z. wiska, 2 - z. łomżyńska, 3 - z. nurska, 4 - z. różańska, 5 - z. ciechanowska, 6 - z. zakroczymska; woj. płockie: 7 — z. zawkrzeńska). Oprac. kartograficzne M. Gochna

utworzona od nazwy osobowej Chojno ani od apelatywu chojna 'sosna', jak przyjmuje się w literaturze przedmiotu' ${ }^{1}$.

Podobnie jest z nazwą wsi Brodowo, gm. Radziłów, w ziemi wiskiej (zob. mapę 2), która powstała po sprzedaży w 1454 r. 10 włók Szczepanowi Kuczowi i Jaszczołdowi z Brodowa, gm. Winnica, w ziemi zakroczymskiej (PPr VI, nr 576; Kapica, nr 22). Nazwa nowej wsi pojawia się w 1465 r. w przekształconym zapisie Brodowsko (MZH, nr 258) oraz w tymże roku jako Brodowo (Kapica, nr 33), a nie w latach 1417 - Brodowo (MK 3, 62) - i 1428 (PPr V, nr 678), ponieważ te poświadczenia odnoszą się do wsi rodzinnej założycieli. Nie jest to zatem nazwa dzierżawcza, od nazwy osobowej i herbowej Broda, ani nazwa topograficzna, wskazująca na istnienie brodu na Wissie, jak przyjmuje się w literaturze toponomastycznej (Zierhoffer 1957: 121; Halicka 1976: 25; Sędziak 2002: 95; NMPol I 342).

${ }^{1}$ Na przykład K. Zierhoffer (1957: 134) uznał tę nazwę za topograficzną, o niejasnym znaczeniu; I. Halicka (1976: 33) błędnie wywiodła ją od nazwy osobowej Chojno i zaliczyła do nazw dzierżawczych, co powtórzono w NMPol (II 64 [5]). Jeszcze większe zamieszanie spowodowała H. Sędziak (2009: 95), myląc dwie miejscowości: Chojnowo i Chojnówek. 
Nazwą przeniesioną jest Obiedzino (Obidzino), gm. Kolno, w ziemi łomżyńskiej (zob. mapę 3), powstałe około 1416 r. (c. 1456), po tym, jak Adam i Marcin z Obiedzina, gm. Gołymin-Ośrodek, w ziemi ciechanowskiej, otrzymali nadanie 30 włók na Skrodą (MK 3,110). Pierwszy zapis nazwy nowej wsi Obidzino pojawia się w 1424 r. (Kapica, nr 370). W 1503 r. mamy poświadczonych dwóch właścicieli tej wsi: Adama i Jana (Jaśka) (MZH, nr 825), co przed 1578 r. zaowocowało podziałem obiektu na dwie części Obidzino Jadami, Obidzino Magna Jaski (ŹDZ XVI 375), o nazwach zestawionych, przy czym łac. przymiotnik Magna wskazuje zapewne na wieś starszą.

Pierwotną postać zachowała nazwa wsi Chełchy, gm. Grabowo, w ziemi wiskiej (zob. mapę 2), założonej po nadaniu z 1439 r. dla Tomka z braćmi z Chełch, gm. Karniewo, w ziemi ciechanowskiej (MK 340, 166), poświadczona od 1476 r. jako Chelchy (MZH, nr 486). Przytaczane w literaturze przedmiotu poświadczenie z 1426 r. (PPr V, nr 228) odnosi się do wsi rodzinnej Tomka (Halicka 1976: 31; NMPol II 27).

Podobnie jest z nazwą wsi Łempice, gm. Wąsosz, w ziemi wiskiej (zob. mapę 2). Wieś o tej nazwie powstała po nadaniu z 1426 r. dla Jana z Łempic (dziś Łępice), gm. Pokrzywnica, w ziemi zakroczymskiej². Nazwa nowej wsi pojawia się w różnej grafii od 1436 r. - Lampicze (MK 335, 68v), 1524; Lampice, Lapice (MZH, nr 995), 1577; Lamipicze (ŹDZ XVI 363). I w tym przypadku zapisy Lampicze z 1426 i 1428 r. (PPr V, nr 228, 776) odnoszą się do wsi macierzystej, a nie leżącej w gm. Wąsosz (tak Halicka 1976: 107).

Nie jest natomiast oczywisty przypadek nazwy wsi Kluki, gm. Kałuszyn, w ziemi liwskiej (zob. Mapa 4). W 1476 [1480] r. odnotowano Stanisława i Klemensa z synami, noszących nazwisko Klukowsczy (KL, nr 236, s. 272). Wedle wszelkiego prawdopodobieństwa pochodzili oni ze wsi Klukowo, gm. Świercze-Koty, w ziemi zakroczymskiej, poświadczonej od 1416 r. (MK 3, 54). Nazwa nowej wsi pojawia się dopiero w 1535 r. - Klukj (ASK I 39, 33v). Tu rodzi się pytanie, czy jest to derywat od nazwy rodzinnej Klukowo, czy nazwa rodowa utworzona od nazwiska założycieli.

Podobnie rzecz się ma z nazwą wsi Chrościce, gm. Kałuszyn, w ziemi liwskiej (zob. mape 4), notowaną dopiero od 1520 r. jako Chrosczycze (Ep. 204, 44-45), ale rodzina Chrościckich przybyła tu już ok. 1470 r., kiedy to Marcin, Jakub oraz Wojciech z synami Mikołajem i Michałem nabyli dobra w ziemi czerskiej od Sułkowskich (Bon 3, s. 97) i w 1474 oraz 1476 [1480] r. pisali się Chrosczyczczy

2 J. Wiśniewski (1975: 71) uznał, że pojawiająca się w literaturze przedmiotu data założenia wsi w 1410 r., znana z tradycji rodzinnej, jest zbyt wczesna.

${ }^{3}$ Jest tu wprawdzie podana omyłkowa data 1611 r., ale trzy spośród wymienionych osób (Marcin, Michał i Mikołaj) są poświadczone w przywileju z 1476 [1480] r. Z 1474 r. znana jest Katarzyna, wdowa po Stanisławie Chrościckim (MK 41,45), a więc rodzina ta musiała tu osiąść przed tym rokiem. $\mathrm{Z}$ tego powodu określenie daty na około $1470 \mathrm{r}$. jest prawdopodobne. Parafia kałuska należała do ziemi liwskiej, która wydzieliła się z ziemi czerskiej, ale w XV w. należące do niej wsie często lokowano w ziemi czerskiej. 


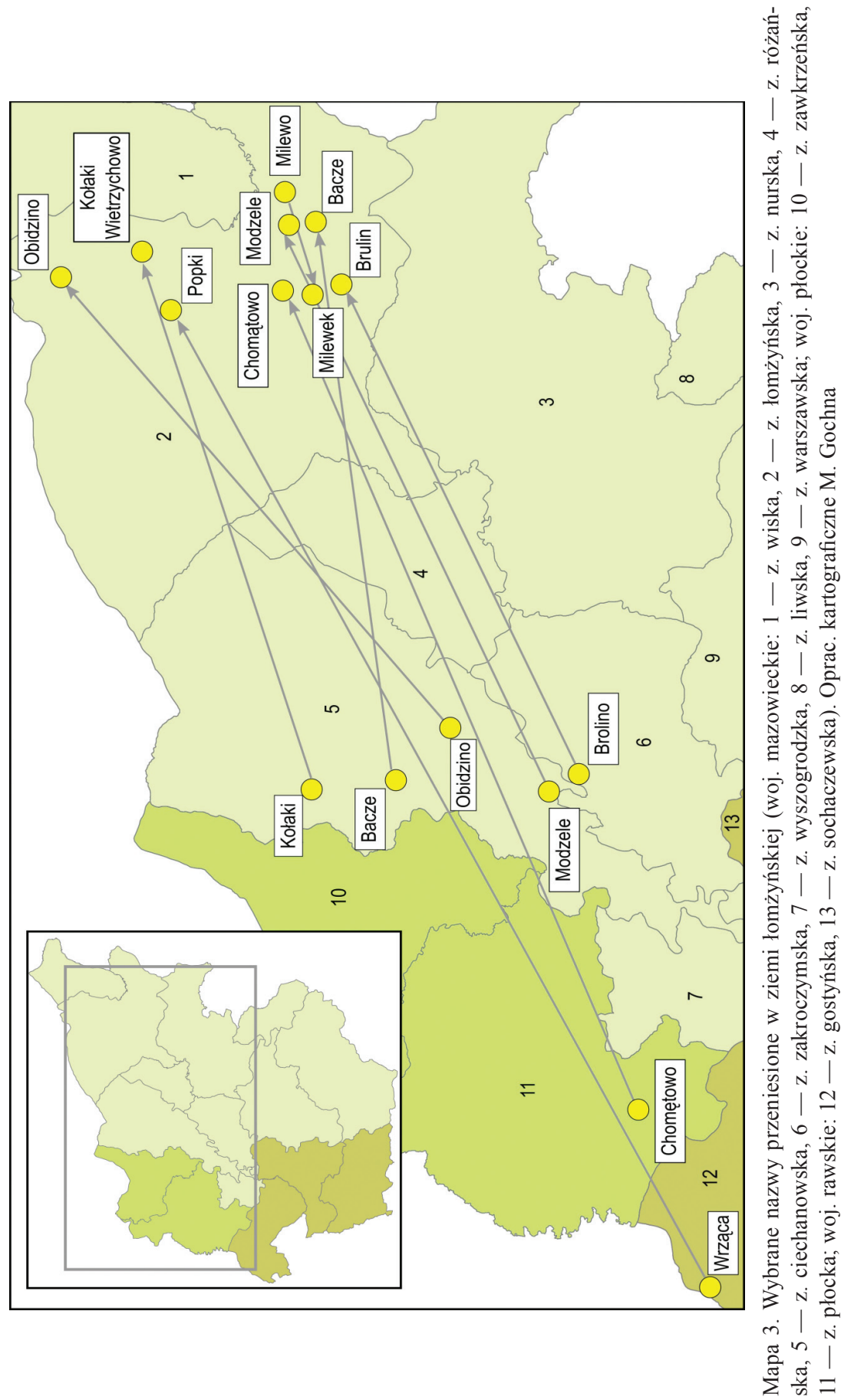




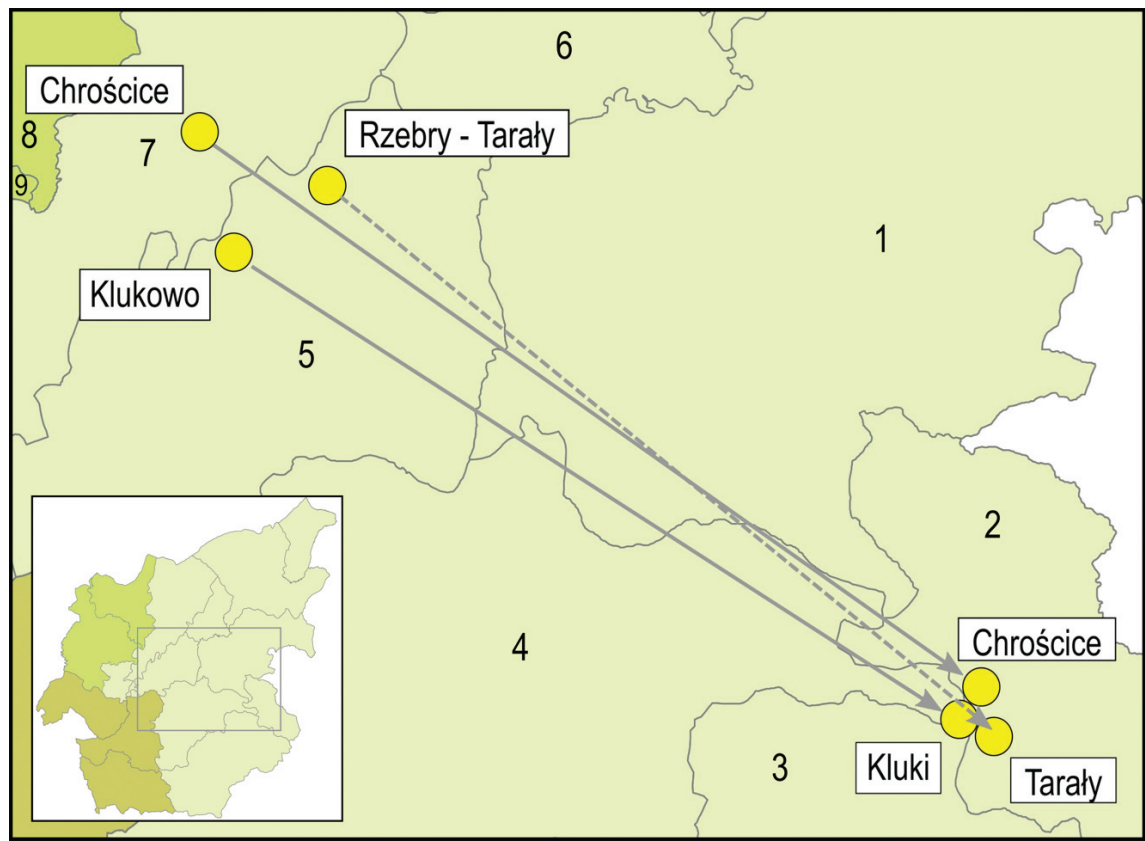

Mapa 4. Wybrane nazwy przeniesione w ziemi liwskiej (woj. mazowieckie: 1 - z. nurska, 2 - z. liwska, 3 - z. czerska, $4-$ z. warszawska, $5-$ z. zakroczymska, 6 - z. różańska, 7 - z. ciechanowska; woj. płockie: 8 - z. zawkrzeńska, 9 - z. płocka). Oprac. kartograficzne M. Gochna

(MK 41, 45; KL, nr 236, s. 272). Ponieważ ród ten był herbu Trzaska, jest prawie pewne, że nazwa wsi została przeniesiona z ziemi ciechanowskiej, gm. Sońsk, gdzie znajduje się wieś o identycznej nazwie (obecnie Chruścice, Chróścice Wielkie), należąca do tego samego rodu herbowego. Nie można jednak wykluczyć, że może to być wtórna nazwa patronimiczna utworzona od nazwiska założycieli wsi.

Przykładem bardziej złożonych relacji jest nazwa zanikłej wsi Tarały, gm. Kałuszyn, w ziemi liwskiej (zob. mapę 4). Wieś powstała po 1469 r., kiedy to Stanisław z Kałuszyna sprzedał 25 włók w Kałuszynie Jarosławowi i jego synom, Stanisławowi Szemborowiczowi, braciom Jakubowi i Michałowi oraz braciom Mikołajowi i Stanisławowi ze wsi Rzebry (dziś Żebry), gm. Gzy, w ziemi zakroczymskiej (MK 5, 103). Należeli oni do rodu Półkoziców (inaczej Rzebro). Na włókach tych powstało kilka wsi, m.in. Tarały, o nazwie zapisanej w $1526 \mathrm{r}$. jako Caluschino Tharaly (MK 41, 169). Tu rzecz ciekawa: w 1576 r. w gm. Gzy istniała również wieś o nazwie Zebry-Tarały (ŹDZ XVI 320). Z braku źródeł nie wiemy zatem, czy nazwa wsi koło Kałuszyna jest nazwą przeniesiona, czy też przodkiem właścicieli obu wsi był ten sam Tarała i nazwę nowej wsi należy uznać za rodową. 
W przypadku niektórych wsi spotykamy się z równoczesnym używaniem dwu nazw: przeniesionej i ponowionej. Przykładem jest nazwa wsi Bacze (dziś Bacze Suche i Mokre), gm. Zambrów i Łomża (zob. mapę 3). Nazwa pojawia się w dokumencie z 1405 r., ale odnoszącym się do ok. 1390 r. — Slassani Bacz, Slasani Bacz (kopia z 1551 r., ADP Ep 17, 385v, 386)4 . Wydaje się jednak, że wieś powstała dopiero w 1398 r. po nadaniu 10 włók, noszących zapewne nazwę Laszany, Pawłowi i jego synowi Stanisławowi de Bacze (Kapica, nr 1), pochodzącym prawdopodobnie ze wsi Bacze, gm. Opinogóra Górna, w ziemi ciechanowskiej. Przemawia za tym zapis z 1409 r., kiedy to Stanisław otrzymał kolejne nadanie 10 włók nemoris dicti Laszany (Kapica, nr 1). Stąd powstała wieś nosiła też nazwę oboczną (ponowioną z nazwy terenowej): 1438 de Lasan (Tym 244, przyp. 117); 1443 de Laszany (Kapica, nr 289); 1443 (c. 1456) r. de Llassan (MK 3, 286); 1470 r. de Llassenya (MK 5, 143v). Niekiedy używano wymiennie obu nazw: 1471 de Bacz, in Lassÿen (MK 6, 2); 1487 r. Lascheny alias Bacze (MK 6, 209). W 1578 r. odnotowano nazwę Bacze Antiqua (ŹDZ XVI 370). Bacze są zatem nazwą przeniesioną, a nie rodową (tak Halicka 1976: 16; nazwy obocznej autorka nie przytacza).

$\mathrm{Z}$ nieco inną sytuacją spotykamy się w przypadku nazwy wsi Modzele, gm. Łomża (zob. mapę 3). Wieś powstała po nadaniu Mikołajowi de Modzele, gm. Nowe Miasto, koło Nasielska, w 1402 r., 20 włók lasu Sokolałaka (Kapica, nr 346). Nazwa wsi, znana z 1405 [1551] r., początkowo była nazwą zestawioną, której człon pierwszy miał formę dzierżawczą, a człon drugi, lokalizujący, był ponowiony z nazwy nadanego lasu - Modzelewo Sokolowalacka, Modzelewo Lacka, Modzelowo Lanka (ADP Ep 17, k. 385v, 386). Może to sugerować, że Mikołaj nosił przydomek utworzony od herbu Modzele. Wkrótce jednak nazwa wsi zmieniła się i w 1426 r. występowała jako Modzele alias Sokolalanka (PPr V, nr 232). I tu rodzi się pytanie, czy Modzele to nazwa przeniesiona z nazwy wsi rodzinnej Mikołaja, czy nazwa rodowa utworzona od jego przydomka. Człon drugi nazwy zanikł w XVI w.

Inny przykład to nazwa wsi Kołaki-Wietrzychowo, gm. Mały Płock, w ziemi łomżyńskiej (zob. mapę 3). Wieś powstała ok. 1417 r., kiedy to Dobiesław z Kołaków, gm. Grudusk, koło Ciechanowa, otrzymał nadanie 40 włók zwanych Wyetrzichowo (MK 3, 117 i 195). Początkowo używano dzierżawczej nazwy wsi Kolakowo/ Kolacowo, znanej od 1430 r. (PPr VI, nr 249), co sugeruje, że Dobiesław mógł nosić przydomek Kolak. Wkrótce, bo w 1438 r., pojawia się nazwa Colaky (MK 3, 216v-217) i znów nie sposób ustalić, czy jest to nazwa przeniesiona, czy derywat od

${ }^{4}$ Dokument ten, wystawiony przez biskupa płockiego Jakuba z Korzkwi (1396[8]-1425), potwierdza erekcję parafii w Śniadowie, dokonaną przez jednego z poprzedników. Tak się jednak złożyło, że nie sposób pewnie ustalić, kim on był. Oto bowiem bezpośrednim poprzednikiem Jakuba z Korzkwi był Maffoplus de Lampugnana (1393-1396), który nigdy nie objął urzędu, nie mógł więc powołać parafii. Przed nim biskupem był Henryk, książę mazowiecki (1390-1393), który nie został wyświęcony, a wcześniej Ścibor z Radzymina (1381-1390). Z tego powodu wydaje się, że erekcja parafii nastąpiła około 1390 r., a dokument wydany w 1405 r. objął także wsie powstałe między 1390 a 1405 r. 
nazwy wsi rodzinnej, czy nazwa dzierżawcza, później rodowa, od przydomka założyciela. W 1493 r. (MK 6, 293) wieś nosi oboczną nazwę Wyetrzichowo (MZH, nr 582, 583), ponowioną z nazwy terenowej nadanych włók, która później — jako człon odróżniający — wejdzie w skład nazwy zestawionej, zapisanej w 1578 r. jako Kolaki Wietrzichowo (ŹDZ XVI 374).

Nie we wszystkich przypadkach, gdy wydaje się, że nazwa nowej wsi jest formalnie równa nazwie wsi rodzinnej założycieli, rzeczywiście tak jest. Przykładem jest kilka wsi o nazwie Truszki w ziemi łomżyńskiej i wiskiej. Gniazdo ich założycieli znajdowało się we wsi Truszki, gm. Gołymin-Ośrodek, koło Ciechanowa (zob. mape 5 - Truszki 1). To jej mieszkaniec, Paweł zwany Truskiem (Paulus Trusk), ok. 1415 r. otrzymał nadanie 20 włók o nazwie Pawłowo w lesie Radgoszcz, przy źródłach Trzcianki, prawego dopływu Rużu (MK 3, 16v) ${ }^{5}$. Powstała tu wieś Truszki (Stare), gm. Śniadowo (zob. mapę 5 - Truszki Stare). Jej nazwa pojawia się w 1421 r.: Truszki (Kapica, nr 558), później, w 1578 r., Truski Stare (ŹDZ XVI 370), a w 1674 r. - Truski Antiqua (RPg I, k. 679). Nadane dobra wkrótce zostały podzielone i powstały nowe wsie o nazwach zestawionych: Truszki-Kruki, Truszki-Pikule, Truszki-Sapki i Truszki-Trzcianka. Nasuwają się zatem pytania, czy wieś Truszki (Stare) to nazwa przeniesiona, czy też nazwa rodowa, powstała od przydomka Pawła, i jak należy zaklasyfikować nazwy wsi powstałych po podziale pierwotnego nadania.

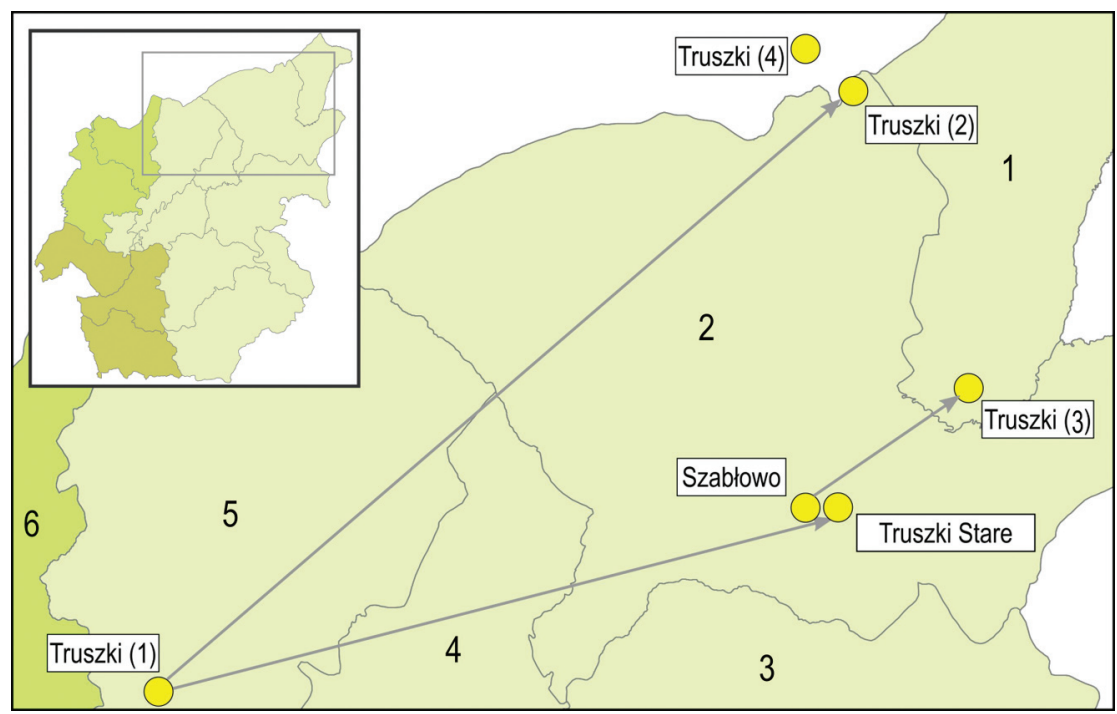

Mapa 5. Nazwy przeniesione Truszki (woj. mazowieckie: 1 - z. wiska, 2 - z. łomżyńska, 3 - z. nurska, $4-$ z. różańska, 5 - z. ciechanowska; woj płockie: 6 - z. zawkrzeńska). Oprac. kartograficzne M. Gochna

${ }^{5}$ Zbieżność nazwy nadanych włók i imienia odbiorcy nadania może sugerować, że osiadł on tu wcześniej i dopiero po zagospodarowaniu własności otrzymał akt nadania. 
Druga wieś, Truszki, gm. Lachowo (zob. mapę 5 - Truszki 2), powstała zapewne w 1419 (ok. 1456) r. (MK 3, 21), po nadaniu dla braci Wojciecha, Krystyna i Bronisza z tychże Truszek w ziemi ciechanowskiej. Obejmowało ono 40 włók zwanych Grothkowo, położonych na początku lasu Kumelsk, w pobliżu Wincenty, lewego dopływu Pisy, w ziemi łomżyńskiej, a nie, jak podaje literatura toponomastyczna, w ziemi wiskiej (Wolff, Rzetelska-Feleszko 1982: 85). Z 1428 r. dysponujemy zapisem: ad granicies Cristini Trusk (PPr V, nr 607), w 1465 r. Trusky (ADP Ep. 9, 188v), a w 1578 r. Truski Zaliesie (ŹDZ XVI 375). Również i ta wieś podzieliła się na Truszki-Kucze i Truszki-Patory.

Trzecią wieś Truszki, gm. Piątnica (zob. mapę 5 - Truszki 3), założył w 1420 r. lub rok wcześniej Stanisław zwany Trusk (Stanislao dicto Trusk) z Szabłowa (dziś Stare Szabły), gm. Śniadowo (MK 3, 123-123v), położonego obok wymienionych wyżej Truszek (Starych), gm. Śniadowo. W tym przypadku mamy do czynienia z nazwą rodową, utworzoną od przydomka Stanisława. Nazwa nowej wsi pojawia się w 1422 r.: Trusky (MK 3, 84).

Następna wieś o nazwie zachowanej w zniemczonym zapisie (Threszken) powstała po północnej stronie granicy mazowiecko-krzyżackiej przed 1448 r., kiedy to Stannicken Trossken (Stanisław Trusk) otrzymał od wicekomtura bałgijskiego dokument na nadmiar posiadanej ziemi (OF 207, f. 120). Później, zapewne po połączeniu się tej wsi z dobrami służebnymi Lemany, wieś nosiła nazwę Bagieńskie, gm. Biała Piska (Białuński 2002: 32-33. 40, 51).

Z przytoczonych zapisów wynika, że tylko wieś w gm. Piątnica nosi nazwę rodową. Nazwy pozostałych wsi mogą być zarówno nazwami przeniesionymi z nazwy wsi rodzinnej ich założycieli, jak i nazwami rodowymi utworzonymi od przydomka noszonego przez członków tej rodziny herbu Bończa.

W nazwach przeniesionych zachodziły czasem zmiany fonetyczne. Przykładem jest nazwa Brulin, gm. Śniadowo, w ziemi łomżyńskiej (zob. mapę 3). Została ona przeniesiona przed 1425 r. z nazwy wsi Brolino (Brodlino, dziś Bruliny, znane od 1425 r., Zakr I, nr 6), gm. Świercze-Koty, koło Pułtuska. Nazwę nowej wsi zapisano w 1425 r. jako Brolino (PPr V, nr 90), a pierwszą zmianę jej brzmienia odnotowano w 1674 r. — Brulino (RPg, cz. II, k. 578), następną zaś na mapie Textora (1806-1808) - Brulin.

Inny przykład to Chomentowo, gm. Śniadowo, w ziemi łomżyńskiej (zob. mapę 3). Wieś powstała przed 1390 r. W tym roku bowiem książę Janusz I przeniósł ją z prawa polskiego na chełmińskie. Wieś należała do Pawła, Jakuba i Krystyna herbu Prus, pochodzących z Chomętowa, gm. Radzanowo, w ziemi płockiej, i nosiła wówczas nazwę Chomanthowo (ok. 1456, MK 4, 94-94v). Spośród wyróżniających się kolejnych jej zapisów odnotujmy w 1405 (1838) r. Chomontowo (ArŁm I, sygn. 495, k. 6v), a w 1513 r. Chomatowo (PT 1, 94v).

Do zmiany budowy nazwy doszło w przypadku wsi Milewek, gm. Śniadowo, w ziemi łomżyńskiej, dziś części Śniadowa (zob. mapę 3). Jej początek wiąże się 
z zakupem w 1428 r. 10 włók ,in Mankan et Jacacz riwlis” przez Piotra z Milewa, gm. Puchały, w ziemi łomżyńskiej, (PPr V, nr 579). Na włókach tych powstała wieś, nazywana w 1464 (1498) r. Mylewo (MK 9, 218), ale już w 1578 r. — Miliewko (ŹDZ XVI 370). Zmiana nazwy miała na celu odróżnienie wsi od nieodległego Milewa. W 1827 r. był to Milewek białodwory (Tabella II 22). W tym przypadku pierwotna nazwa przeniesiona uległa zdrobnieniu, aby następnie stać się członem nazwy zestawionej.

Innym zmianom podlegała nazwa wsi Bukowo (Duże i Małe), gm. Wąsosz, w ziemi wiskiej (zob. mapę 2), którą założyli po nadaniu z 1428 r. Stanisław, Falisław, Jan, Awdaniec i Henryk, pochodzący zapewne z Bukowca (dziś Bukowiec Mały i Wielki), gm. Janowiec Kościelny, na Zawkrzu (de Bukowecz, PPr V, nr 694). Obie wsi zamieszkiwała szlachta herbu Awdaniec. Nazwa nowej wsi brzmiała początkowo (1437) Bukowecz (MK 336, 66) ${ }^{6}$, następnie w 1483 r. Bukowo (MZH, nr 654), choć jeszcze w 1497 r. pojawia się forma Bukowecz (CBK 4, nr 219). W czasach nowożytnych wieś podzieliła się na Bukowo Wielkie (później Duże) i Bukowo Mate (Tabella I 57; Skorowidz V 94). Nie jest to zatem nazwa topograficzna ${ }^{7}$, a nazwa przeniesiona, z wtórną zmianą struktury.

Podobny proces obserwujemy w przypadku nazwy wsi Kownacin, gm. Grabowo, w ziemi wiskiej (zob. mapę 2). Wieś powstała po nadaniu z 1425 r. dla Daćboga i synów Bogusława i Augustyna z Kownat, gm. Piątnica, w ziemi wiskiej (PPr V, nr 110), gdyż w 1439 r. mamy tu poświadczonego Bogusława syna Daćboga (MK $335,101)$. W podstawie jej nazwy tkwi nazwa herbowa Suche Kownaty. Nowa wieś początkowo nosiła nazwę Kownathy (1426, MK 335, 99), w 1443 r. Kownati (PPr V, nr 481); w 1502 r. pojawia się nowa forma Cownaczyno (MZH, nr 820). W przypadku tej nazwy nie mamy pewności, czy jest to nazwa rodowa utworzona od nazwy herbu lub nazwy osobowej, czy nazwa przeniesiona, która na koniec uległa derywacji.

Ciekawym przypadkiem jest nazwa wsi Popki, gm. Mały Płock, w ziemi łomżyńskiej (zob. mapę 3). Przypadek ten wiąże się z próbą rekonstrukcji najstarszej nazwy tej wsi. Oto w miejscu jej założenia przed 1415 r. istniała starsza wieś o nazwie Dlugistok, ponowionej od niepotwierdzonej źródłowo nazwy cieku, lewego dopływu Czetny. Po opuszczeniu tej wsi przez jej właściciela, Mikołaja zwanego Piątek (Nicolaus dictus Pyonthek, PPr V, nr 32, zapis z 1425 r.), nadanie otrzymali bracia Piotr Białasuknia i Marcin z rodu Soleckich herbu Pomian, właściciele wsi koło Gostynina, w tym wsi Wrząca, gm. Rataje (Wrancza - PPr V, nr 237; Pacuski 2009: 179-180). Choć najstarsza nazwa nowej wsi nie została

${ }^{6}$ W herbarzu Kapicy (nr 183) formę dzierżawczą odnotowano już w 1437 r., ale autor tej pracy wielokrotnie podawał nazwy wsi w wersji z przełomu XVIII i XIX w., a nie formy zawarte w wykorzystanych aktach.

${ }^{7}$ K. Zierhoffer (1957: 127) podał błędne odniesienie: 1497 r. — Bukowecz (CBK 4, s. 4 nr 226), co powtórzyła H. Sędziak (2009: 93). 
poświadczona w źródłach, można postawić hipotezę, że osada mogła nosić nazwę przeniesioną *Wrzqca, wkrótce nastapiła bowiem zmiana nazwy strumienia z Długiegostoku na Wrzacystok. To z kolei już w 1432 r. znalazło odzwierciedlenie w nowej, zestawionej nazwie wsi - Białosuknie Wrzacystok (Gloger 1876: 10) oraz w nazwie włók Wrzanczesthoky (1484 r., MK 6, 172v). W 1472 r. wieś nosiła nazwę Białesuknie (ADP Ep. 10, 43), a w 1578 r. pojawia się nazwa zestawiona Popki Bialesuknie (ŹDZ XVI 374). W 1693 r. są to już tylko Popki (ADP AW 1693 r., sygn. 47, k. 405). W podstawie nazwy rodowej Popki tkwi przezwisko nadane Janowi z tej wsi (Johannes de Byalessuknye alias Popek), odnotowane w 1472 r. (ADP Ep 10, 43).

Powyższe przykłady pokazują, z jakimi elementami poznania historycznego musimy się zmierzyć, gdy chcemy ustalić genezę konkretnej nazwy miejscowej na północno-wschodnim i wschodnim Mazowszu w jego historycznych granicach. Dodać jeszcze trzeba, że większość zasygnalizowanych problemów odnosi się do całości badań toponimii polskiej.

\section{LITERATURA}

ADP Ep - Archiwum Diecezji Płockiej, Episcopalia (księgi sądów biskupich).

ADP AW - Archiwum Diecezji Płockiej, Akta wizytacji.

AGAD - Archiwum Główne Akt Dawnych w Warszawie.

AHPLub - Atlas historyczny Polski. Mapy szczegółowe XVI wieku, t. 3: Województwo lubelskie w drugiej połowie XVI wieku, red. W. Pałucki, oprac. S. Wojciechowski, PWN, Warszawa 1966.

AHPMaz - Atlas historyczny Polski. Mapy szczegółowe XVI wieku, t. 7: Mazowsze w drugiej połowie XVI wieku, red. W. Pałucki, PWN, Warszawa 1973.

AHPPrusy - Atlas historyczny Polski, seria B: Mapy przeglqdowe, t. 1: Prusy Królewskie w drugiej połowie XVI wieku, oprac. M. Biskup przy współudziale L. Koca, red. S. Herbst, PWN, Warszawa 1961.

AHPSand - Atlas historyczny Polski. Mapy szczegółowe XVI wieku, t. 2: Województwo sandomierskie $w$ drugiej polowie XVI wieku, red. S. Trawkowski, PWN, Warszawa 1993.

AHPSŁ — Atlas historyczny Polski. Mapy szczegółowe XVI wieku, t. 5: Województwo sieradzkie i województwo tęczyckie w drugiej połowie XVI wieku, red. H. Rutkowski, Wyd. Instytutu Historii PAN, Warszawa 1998.

AHPKrak - Atlas historyczny Polski. Mapy szczegółowe XVI wieku, t. 1: Województwo krakowskie $w$ drugiej polowie XVI wieku, red. H. Rutkowski, Wyd. Instytutu Historii PAN-Neriton, Warszawa 2008.

ArŁm - Archiwum Diecezjalne w Łomży.

ASK - Archiwum Skarbu Koronnego, AGAD.

Atlas Fontium - Atlas Fontium, www.atlasfontium.pl (dostęp 29 XI 2016).

Białuński G. 2002: Kolonizacja ,Wielkiej Puszczy” (do 1569 roku) - starostwa piskie, ełckie, straduńskie, zelkowskie i węgoborskie (węgorzewskie), Ośrodek Badań Naukowych im. W. Kętrzyńskiego, Olsztyn.

Bon - A. Boniecki, Herbarz Polski, t. 3, Warszawa 1900. 
Borek H. 1988: Nazwy relacyjne w toponimii, w: K. Zierhoffer (red.), V Ogólnopolska Konferencja Onomastyczna. Księa referatów, UAM, Poznań, s. 43-51.

Bubak J. 1965, 1966: Nazwy przeniesione w polskiej toponimii, „Onomastica” X, s. 50-73; XI, s. 43-61 .

CBK 4 - I. T. Baranowski, Spis rycerstwa powiatu Wizkiego i Wasoskiego, które uczestniczyło w wyprawie wotoskiej 1497 r., „Collectanea Biblioteki Ordynacji hr. Krasińskich” 4, Warszawa 1913.

CRP - Corona Regni Poloniae, mapa w skali 1 : 250 000, Instytut Historii PAN, „Atlas Źródeł i Materiałów do Dziejów Dawnej Polski”, 2004, 1, http://atlasfontium.pl (dostęp 29 XI 2016).

Gloger Z. 1876: Dawna ziemia tomżyńska [odbitka z „Biblioteki Warszawskiej” 2 (142), s. 1-20].

Górnowicz H. 1967: Rodowe nazwy miejscowe Podlasia, „Onomastica” XII, s. 5-69.

Górnowicz H. 1968: Rodowe nazwy miejscowe Wielkopolski, Małopolski i Mazowsza, „Gdańskie Zeszyty Humanistyczne. Filologia Polska" 10, nr 3.

Halicka I. 1976: Nazwy miejscowe środkowej i zachodniej Białostocczyzny. Dzierżawcze, patronimiczne i rodzinne, PWN, Warszawa.

Halicka I. 1978: Nazwy miejscowe środkowej i zachodniej Białostocczyzny. Topograficzne i kulturowe, PWN, Warszawa.

Jurek T. 2010-2016: Wprowadzenie, [w:] Stownik historyczno-geograficzny ziem polskich w średniowieczu, red. T. Jurek, http://www.slownik.ihpan.edu.pl (dostęp 29 XI 2016).

Kapica - Herbarz Ignacego Kapicy Milewskiego (dopetnienie Niesieckiego), wyd. Z. Gloger, Kraków $1870^{8}$.

Karaś M. 1971: Słowiańskie nazwy miejscowe i ich klasyfikacje (Uwagi i propozycje), „Biuletyn Polskiego Towarzystwa Językoznawczego" XXVIII, s. 63-86.

Korona - Ziemie polskie Korony w XVI w. Przestrzenna baza danych, Instytut Historii PAN, http:// atlasfontium.pl (dostęp 29 XI 2016).

Kwater - Topograficzna karta Królestwa Polskiego, Warszawa 1839 (1843), skala 1: 126000.

MK - Metryka Koronna, AGAD.

MZH — A. Wolff, Mazowieckie zapiski herbowe z XV i XVI wieku, AU, Kraków 1937.

NMPol - Nazwy miejscowe Polski. Historia. Pochodzenie. Zmiany, t. I-VII $(A-N)$, red. K. Rymut, IJP PAN-DWN, Kraków 1996-2007; t. VIII-XI $(O-R)$, red. K. Rymut, B. Czopek-Kopciuch, U. Bijak, Kraków 2009-2015.

OF 207 — Ordensfolianten, Geheimes Staatsarchiv, Preussischer Kulturbesitz, Berlin-Dahlem.

Pacuski K. 2009: Możnowładztwo i rycerstwo ziemi gostynińskiej w XIV i XV wieku. Studium z dziejów osadnictwa i elity władzy na Mazowszu średniowiecznym, Neriton, Warszawa.

Pacuski K. 2015: Materiały do stownika historyczno-geograficznego ziemi liwskiej w średniowieczu $i$ w XVI wieku, Instytut Historii PAN, „Atlas Źródeł i Materiałów do Dziejów Dawnej Polski”, http://atlasfontium.pl (dostęp 29 XI 2016).

Panecki T., Związek T. 2016: Materiaty do badań nad rekonstrukcja zalesienia na Równinie Nowotomyskiej w XVI w., Instytut Historii PAN, http://atlasfontium.pl (dostęp 29 XI 2016).

Perthées K. 1783: Mappa szczegulna woiewodztwa mazowieckiego, skala 1: 225000.

PPr - Metryka Księstwa Mazowieckiego z XV-XVI w., t. 1: Księga oznaczona nr 333 z lat 1417-1429, wyd. A. Włodarski, „Pomniki Prawa” V, Warszawa 1918; t. 2: Księga oznaczona nr 334 z lat 1429-1433, wyd. A. Włodarski, „Pomniki Prawa” VI, Warszawa 1930.

PT — Księgi pultuskie grodzkie testamenta, AGAD.

Ptaszyński M. (red.) 2014: Zestawienie zborów protestanckich w Rzeczypospolitej w XVI-XVIII wieku, Instytut Historyczny UW, http://atlasfontium.pl (dostęp 29 XI 2016).

Rospond S. 1957: Klasyfikacja strukturalno-gramatyczna stowiańskich nazw geograficznych, PWN, Wrocław.

${ }^{8} \mathrm{~W}$ wielu przypadkach zapis nazw miejscowych zawartych w tej pracy nie jest oryginalny. 
RPg — Rejestr pogłównego z 1674 r., AGAD I, ASK, sygn. 66, cz. I, k. 678-682, 750v-753; cz. II, k. $576 \mathrm{v}-578$.

RPKal - Rejestry poborowe województwa kaliskiego w XVI wieku, Instytut Historii PAN, „Atlas Źróder i Materiałów do Dziejów Dawnej Polski”, 2015, 2, red. M. Słoń, http://atlasfontium.pl (dostęp 29 XI 2016).

RPPoz - Rejestry poborowe województwa poznańskiego, Instytut Historii PAN, „Atlas Źródeł i Materiałów do Dziejów Dawnej Polski”, 2015, 3, red. M. Słoń, http://atlasfontium.pl (dostęp 29 XI 2016).

Sędziak H. 2002: Nazwy złożone wsi drobnoszlacheckich $w$ ziemi łomżyńskiej, „Białostockie Archiwum Językowe" 2, s. 117-129.

Sędziak H. 2003: Dzierżawcze nazwy wsi drobnoszlacheckich w ziemi łomżyńskiej, „Białostockie Archiwum Językowe" 3, s. 163-176.

Sędziak H. 2004a: Nazwy wsi drobnoszlacheckich w powiecie kolneńskim, „Studia Łomżyńskie” 15, s. $249-268$.

Sędziak H. 2004b: Rodowe nazwy wsi drobnoszlacheckich w Łomżyńskiem, [w:] H. Sędziak (red.), „Polszczyzna Mazowsza i Podlasia” VIII: Antroponimia i toponimia Mazowsza i Podlasia, ŁTN, Łomża s. 25-42.

Sędziak H. 2006: Nazwy wsi drobnoszlacheckich w powiecie grajewskim, „Studia Łomżyńskie” 17, s. $7-28$.

Sędziak H. 2008: Nazwy wsi drobnoszlacheckich w powiecie wysokomazowieckim, „Studia Łomżyńskie” 19 , s. 61-99.

Sędziak H. 2009: Nazwy wsi drobnoszlacheckich w Łomżyńskiem, ŁTN, Łomża.

SHG - Slownik historyczno-geograficzny ziem polskich w średniowieczu, red. T. Jurek, http://www. slownik.ihpan.edu.pl (dostęp 29 XI 2016).

Skorowidz V — Skorowidz miejscowości Rzeczypospolitej Polskiej opracowany na podstawie pierwszego powszechnego spisu ludności z dn. 30 IX 1921 r., [t.] V: Województwo Biatostockie, Warszawa 1924.

Szady B. 2016: Religie i wyznania w Koronie w II połowie XVIII w., „Atlas Źródeł i Materiałów do Dziejów Dawnej Polski”, 1, http://atlasfontium.pl (dostęp 29 XI 2016).

Szady J. 2014: Księgozbiory parafialne prepozytury wiślickiej w II połowie XVIII w., http://atlasfontium.pl (dostęp 29 XI 2016).

Tabella - Tabella miast, wsi, osad, Królestwa Polskiego, z wyrażeniem ich położenia i ludności [...], t. I-II, w drukarni Łątkiewicza, Warszawa 1827.

Taszycki W. 1958: Stowiańskie nazwy miejscowe (Ustalenie podziału), [w:] tenże, Rozprawy i studia polonistyczne, t. 1: Onomastyka, Ossolineum, Wrocław, s. 228-268.

Textor - J. Ch. von Textor, Topographisch-Militaerische-Karte von vormaligen Neu Ost-preussen.., skala $1: 150$ 000, Berlin 1806-1808.

Treder J. 1979: Nazwy ponowione wśród nazw przeniesionych, „Onomastica” XXIV, s. 19-43.

Tym - K. Tymieniecki, Ksztaltowanie się spoteczeństwa średniowiecznego (Polska na tle Stowiańszczyzny zachodniej), t. I: Procesy twórcze formowania się społeczeństwa polskiego w wiekach średnich, Wyd. Poznańskie, Poznań 1996.

Wiśniewski J. 1975: Dzieje osadnictwa w powiecie grajewskim do połowy XVI w., [w:] M. Gnatowski, H. Majecki (red.), Studia i materiaty do dziejów powiatu grajewskiego, t. 1, PWN, Warszawa, s. 9-252.

Wolff A., Rzetelska-Feleszko E. 1982: Mazowieckie nazwy terenowe do końca XVI wieku, PWN, Warszawa.

Zakr I — Księgi zakroczymskie grodzkie wieczyste, AGAD.

Zierhoffer K. 1957: Nazwy miejscowe pótnocnego Mazowsza, Ossolineum, Wrocław.

ŹDZ XVI — Polska XVII wieku pod względem geograficzno-statystycznym, t. V Mazowsze, wyd. A. Pawiński, „Źródła Dziejowe” XVI, Gebethner i Wolff, Warszawa. 


\section{TRANSFERRED NAMES IN EASTERN AND NORTHEASTERN MASOVIA (THE END OF $14^{\mathrm{TH}}-15^{\mathrm{TH}}$ CENTURY)}

\section{SUMMARY}

This paper presents problems occurring during research on origins of names of settlements which were established within a large settlement action organised by prince Janusz I and continued by his successors (the turn of the $15^{\text {th }}$ century). Those problems were illustrated by an example of more than 20 transferred names. Considerations are presented on two levels: historical and toponymical. The main historical source base refers to two areas of eastern and northeastern Masovia - the region of Liw and the regions of Łomża and Wizna. Main criteria that could help researchers to identify the home villages of settlers are presented, as well as changes in the form of new names, and establishing new names based on different name foundations. Those analyses are elaborated, partially, by using data published at the "Atlas Fontium" digital platform, created and developed in the Historical Atlas Section of the Tadeusz Manteuffel Institute of History, Polish Academy of Sciences, Warsaw.

Keywords: Masovia, Middle Ages, transfer of names, toponomastics 